\title{
The Social Function of History and Memory in the Conception of Child in the Constitution and Statute of the Child and Adolescent in Brazil
}

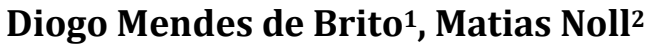 \\ ${ }^{1}$ Federal University of Goiás, Goiânia, Brazil \\ ${ }^{2}$ Instituto Federal Goiano, Ceres, Brazil \\ Email: diogomendesdebrito@gmail.com
}

How to cite this paper: de Brito, D. M., \& Noll, M. (2019). The Social Function of History and Memory in the Conception of Child in the Constitution and Statute of the Child and Adolescent in Brazil. Creative Education, 10, 1914-1928.

https://doi.org/10.4236/ce.2019.108138

Received: February 16, 2019

Accepted: August 18, 2019

Published: August 21, 2019

Copyright () 2019 by author(s) and Scientific Research Publishing Inc. This work is licensed under the Creative Commons Attribution-NonCommercial International License (CC BY-NC 4.0). http://creativecommons.org/licenses/by-nc/4.0/

\begin{abstract}
The promulgation of the Brazilian Federal Constitution in 1988, inaugurated a new view about the child: that of a subject who has rights. However, it was with the Statute of the Child and Adolescent in 1990 that the concept of child became clearer, and perhaps because of this, in its twenty-nine years of existence, the Statute has been the main target of different public policy proposals aimed at children and adolescents. Thus, this article aims to propose a reflection on the social function that history and the study of memory can play on the child and its concept expressed in the Brazilian Federal Constitution and Statute of the Child and Adolescent, since the direction of policies aimed at children expressed in these documents depends on how the child and his childhood are understood throughout history, and therefore, history, as a specific form of scientific production, has a fundamental role.
\end{abstract}

\section{Keywords}

Social Function, History, Memory, Childhood, Child

\section{Introduction}

History is a field of human knowledge that, unlike the natural or biological sciences, is almost always surrounded by particular fragility-it is science for some and not for others, it is just a pure and simple literary art for some and for others it is a particular form of non-literary narrative construction, it is a look at the past in isolation for some and for others this look only occurs in function of the present-precisely because of its specific scientific character.

Thus, the present text brings a discussion about history and its social function 
in the policies for children described in the Federal Constitution of Brazil and the Statute of the Child and Adolescent. The first part is divided into three parts, with a brief presentation of final considerations. It highlights the contributions of the book History and Memory (2013) by the French historian Jacques Le Goff (1924-2014) for the debate on the scientific character of history and its social function. Then, in a second subtitle, also based on the work of the French historian, we make a brief discussion about memory, its "uses" and its social function over time.

The second part of this text, also divided into two subtitles, brings a discussion about the meanings of a child's historical production as about its peculiarities. If before the child was linked to an image of adults, i.e., a "mini-adult", now history, at least from the second half of the twentieth century onwards, sees childhood as a phase with its particularities that such a distinction makes possible the production of a history, so to speak, purer, or better, a history of childhood by childhood. Together with this, a reflection is also made about the social function of memory around the child.

Finally, in the third part, we address the concept of child expressed in the Federal Constitution of 1988 and the Statute of the Child and Adolescent of 1990 , since we consider these normative documents to be a rich example of how the concept of child and childhood is absorbed today in society in general, but not generalized. We also address how the various proposals for changes in laws expressed in these documents are reflections of conceptual changes that occur around the child over time, in order to think about how history can become a protagonist in these constant forms of seeing children and their childhood, in order to prevent possible oppressive actions built on a concept that is changing throughout history.

\section{The Social Function of History and Memory and Its Conceptions over Time}

\subsection{The "Science" of History and Its Social Function}

The French medievalist Jacques Le Goff (1924-2014), in the first text of his book History and Memory, named History, brings us a rich reflection on history and how it has been situated-conceptualizing it-over time. Because of its "social function" history and its conceptualization continue to be diversified, even though it seems to enjoy a certain conceptual solidification in contemporaneity.

One of the problems presented by Le Goff in the first part of his essay (2013), is the understanding of history as a science solely focused on the past or as a scientific knowledge of the past so that it only makes sense if it is linked to the present. In the course of his writing, it is noticed that Le Goff, agreeing with other historians, sees the scientificity of history in a particular way, not only as a simple and isolated science of the past but as a science that enables man, a social subject, to understand himself in time, seeking meanings of the present in the past and vice-versa. In this sense, Marc Bloch (1886-1944), another French his- 
torian, intended to define what shapes the human and especially the social character of history. This is best understood as follows:

This conception of human history invites many historians to think that the central and essential part of history is social history. Charles Edmond Perrin wrote about Marc Bloch: "He states that the object of study of history is the man as part of a social group"; and Lucien Febvre adds: "Not the man, once again, not the man, never the man. Human societies, organized groups" (Le Goff, 2013: p. 27).

Le Goff adds that Bloch "considered that history should not only allow us to understand the 'present by the past' - a traditional attitude - but also to understand the 'past by the present"'1. This temporal relationship, combining past and present, is not something that only Marc Bloch shares, since, before Bloch, the philosopher, historian, and politician, Benedetto Croce (1866-1952) already stated that "all history" is, so to speak, "contemporary history"2. For Le Goff, this way of understanding history brings certain ambiguities, because while it considers history "fruitful", since the historianuses the present to interpret the past, it also considers it "dangerous" in the sense that the past is, so to speak, hostage of the construction that the historian makes of this, once this produced past is related to the present lived by the historian (Le Goff, 2013). In this regard, the medieval historian states that:

This dependence of the past on the present in history should lead the historian to take certain precautions. It is inevitable and legitimate since the past does not stop living and becoming present. This long duration of the past should not, however, prevent the historian from distancing himself from the past, a reverent distance, necessary for him to respect it and avoid anachronism (Le Goff, 2013: p. 29).

The inevitable relationship between past and present does not annul the scientific character of history. Le Goff's warning of the historian's detachment from the past in order to avoid a possible anachronism is one-not the only-precise aspect of this non-scientific annulment of history. We will talk more about this scientificity of history in the course of the text.

Any form of scientific production, whether of the natural, biological or human sciences, generates an aspect of specific functionality, whether social or not. In medicine, for example, its scientific production generates a social or non-social function-highly depending on who will benefit from this production-of its own, which we can say here is a healing function. The same is true for history, given that the past/present relationship is the causal factor of a specific social function. In the words of Le Goff:

This interaction between past and present is called the social function of the past or of history. Thus, for Lucien Febvre (1949): "History systematically 
collects, classifying and grouping past events according to its current needs. It questions death from life. It organizes the past according to the present: this could define the social function of history" (Le Goff, 2013: p. 29).

It is only possible to understand this form of social function of history when one considers factors such as, the historical period in which a given historical production was written. Le Goff, during his essay (2013) - History_brilliantly provides us with examples of historical productions marked by the characteristics of his present time, demonstrating how each era expressed/express its "mental representation of the historical past" (Le Goff, 2013: p. 30).

For Jacques Le Goff, the historian and his historical production are not immune to the dominant presence of the so-called "historical culture"3; even though its subjectivity, in a certain way, distances it from the collective historical mentality. ${ }^{4}$ There is an almost redundant obviousness regarding the collective historical mentality: it is also configured as a specific phenomenon of each society and/or period, which is molded by a set of particular complex factors-political, ethnic, religious, identity, and so on. The study of the history of history is configured as one of the most efficient, if not the only, ways of perceiving in existing historical productions the presence of these elements that form the historical mentality of a specific society. In this regard, Le Goff forewarns: that "the history of history should not be concerned only with the professional historical production, but with a whole set of phenomena that constitute the historical culture, or rather, the historical mentality of an era" (2013: p. 50).

To each type of collective historical mentality-historical culture-is linked a type of specific historical practice whose interests, be they social, political and/or religious, appear in most historical productions of a given time.

The collective historical mentality-historical culture-, which depends, but not only ${ }^{5}$, on the present/past relationship, can also be considered the basis of different understandings of what history will be and the role it plays in society. This apparently "partial" character, in which the characteristics of a society situated in a given time and space are present in historical activity, has made, and still makes, history face problems of theoretical and even methodological origin. Nevertheless, Le Goff proposed a reflection on the philosophies of history.

When talking about "philosophy of history", the author forewarns us and ${ }^{3}$ Although the concept of "historical culture" belongs to another French historian, Bernard Guenée, Le Goff makes a certain conceptual addition by using it. In the words of Le Goff: "Under this term, Guenée brings together the professional background of the historian, his library of historical works, the public and the audience of historians. I add to them the relationship that a society, in its collective psychology, maintains with the past" (2013: p. 49).

${ }^{4}$ Le Goff says: "I will consider historians the main interpreters of collective opinion, seeking to distinguish their personal ideas from the collective mentality". In other words, it is understood here that, despite the particularities of the historian, one of the elements that legitimizes their works as a historical production, is precisely this capacity to interpret and describe, whether conscious or unconscious, the existing historical mentality of a given society.

${ }_{5}^{5}$ Jacques Le Goff, states that "the historical culture (or mentality) does not depend only on the relationships memory-history and present-past. History is the science of time. It is closely linked to the different conceptions of time that exist in a society and is an essential element of the mental apparatus of its historians" (2013: p. 54). 
points out the possible danger of consolidating history as a scientific activity, since for him, philosophy and history can be found in authors such as Fustel de Coulanges, which invalidates talking about "philosophy of history", because the independence of each one is an important factor in their consolidation as unique forms of production of knowledge. His interest in speaking of "philosophy of history" lies in the fact that he analyzes "intellectual models" whose the greatest contribution is to offer a reflection on history and studies of a historiographical nature in general. For this, he used individual examples of thoughts from authors such as Thucydides, Augustine, Vico, Hegel, Marx, Croce, Gramsci, and Foucault.

\subsection{The Conceptions of Memory in History and Its Social Function}

In his book History and Memory (2013), Le Goff dedicates an essay to the issue of Memory and its use in History. In his essay entitled Memory, the historian presents a reflection on the existing relationship between memory and history, both in ancient societies without writing and in so-called modern societies, where the function of memory is conceived differently.

In the first part of his text, the French historian presents us with concepts of memory in non-historical sciences. Memory is not constituted as an object of study belonging only to the human sciences-anthropology or history-but also, according to its conceptual understanding, to the field of psychology, neurophysiology, psychiatry, and so on. Memory and its psychic function is something that directly connects it to history, since "memory, as the property of preserving certain information, refers us in the first place to a set of psychic functions, thanks to which man can update impressions or past information, or that he represents as past information" (Le Goff, 2013: p. 387). However, when memory is addressed by the field of history, it has a specific conceptualization, where the so-called collective memory is more relevant. Le Goff makes an interesting analogy between memory and its use in the psychoanalytic and/or psychological field and memory from the historical point of view:

Finally, psychoanalysts and psychologists have insisted, either on the subject of memory or the subject of forgetfulness (particularly in the wake of Ebbinghaus), on the conscious or unconscious manipulations that interest, affectivity, desire, inhibition, censorship exert on individual memory. In the same way, collective memory has been importantly put into play in the struggle of social forces for power. Becoming masters of memory and forgetfulness is one of the major concerns of the classes, groups, and individuals who have dominated and dominate historical societies. The forgetfulness and silence of history reveal these mechanisms of manipulation of collective memory (Le Goff, 2013: p. 390).

Therefore, memory and its use in history can be configured as an efficient instrument of power in societies, depending, of course, on how this memory is used. 
Just as the historical mentality manifests differently in different societies and historical periods, so it is with memory. In order to offer a broad reflection on memory, Jacques Le Goff, presents us the different manifestations of collective memory over time, highlighting the crucial difference in memory existing in the so-called unwritten societies and unwritten societies.

The French historian indicates some differences and similarities between the so-called unwritten societies and the memory of written societies. One of the connecting points is that, in both unwritten and written societies, memory and its mechanisms of accumulation are part of everyday life (Le Goff, 2013). However, the author shows us a first divergent point of unwritten societies, since "the first domain in which the collective memory of unwritten societies is crystallized is the one that gives foundation-apparently historical - to the existence of ethnic groups or families, i.e., that of myths of origin" (Le Goff, 2013: p. 392). The author also emphasizes that in these so-called unwritten societies, collective memory seems to function in a kind of "generative reconstruction" and not mechanics, where the supports of memory maintenance seem to be less superficial than in so-called written societies.

With the emergence of writing, the author of History and Memory shows us the profound transformation that has occurred in the collective memory. In the words of Le Goff:

Writing allows collective memory to make double progress, developing two forms of memory. The first is the commemoration, the celebration through a commemorative monument of a memorable event. The memory then takes the form of inscription raising in modern times an auxiliary science of history, the epigraphy (2013: p. 394).

Therefore, the second form is the document written on a medium specifically intended for the exercise of writing. In this regard, he states that:

In this type of document, writing has two main functions: "One is the storage of information, which allows communicating through time and space, providing the man with a process of marking, memorization, and recording"; the other, "by ensuring the passage from the auditory to the visual sphere", allows, "re-examine, reorder, and rectify sentences and even isolated words" (Le Goff, 2013: p. 396. Author’s emphasis).

With the appearance of writing, memory becomes, so to speak, palpable. Memory can now be re-examined, something that can be readapted according to particular or collective interests. Now that there is an urban memory, a funerary memory, a memory of kings, memory institutions are created-library, archives, and museums-that serve different interests, be they political, religious and so on, but that their use and development will depend, of course, on the evolution of each society and each historical period. Le Goff highlights that along with the emergence of writing there was an emergence of a real memory, in which kings express through writing their achievements, as is the case of the Ancient East, 
"the evolution towards a history of collective memory is clearly perceived in the case of the Greeks" (2013: p. 399).

Still on the Greeks, it is worth mentioning Plato's emphasis on the emergence of writing and its contribution to oblivion, while, on the other hand, the Greeks of the archaic period were the first to sacralize memory, after all, Mnemosyne is memory incarnated as a goddess (2013: p. 400). The Greeks also created the technique of "stimulating" memory: mnemotechnic. In addition to divinizing memory, the ancient Greeks created memory techniques.

Memory gains other characteristics in the medieval age, when Christianity was the religious and ideological basis. The French historian points out that Judaism and Christianity, to which history owes its institutional and theological consolidation, are constituted as the "religions of remembrance". In the words of the author:

Judaism and Christianity, religions rooted historically and theologically in history, can be described as "religions of remembrance". Also, this is true for different aspects: because divine acts of salvation situated in the past form the content of faith and the object of worship, but also because the sacred book, on the one hand, and the historical tradition, on the other hand, insist, in some essential aspects and on the need for remembrance as a fundamental religious task (Le Goff, 2013: p. 405).

The memory in medieval Christianity is configured as a daily activity. The Bible itself, in the New Testament, invites Christians to live these memories following in the footsteps of their teacher, Jesus Christ. The Catholic rites-Mass-, for example, are an exercise of memory par excellence.

In the Renaissance period, memory was revolutionized by the invention of the press, even if slowly, as happened in China (Le Goff, 2013). The author emphasizes that the effects of the press were more "devastating" from the eighteenth century in Europe, thanks to an effervescent idea of progress of science and philosophy (Le Goff, 2013). The modern period is the period in which there is an "enlargement of the memory".

There were two specific forms of memory exercise in the turn of the nineteenth century to the twentieth: 1) the monument to the dead in which, even unknown soldiers from a war, come to have their memory, often forgotten, and 2) photography, which "multiplies it and democratizes it, gives it a visual precision and truth never before reached, thus allowing to keep the memory of time and chronological evolution" (Le Goff, 2013: p. 426).

Finally, the contemporary age develops a revolutionary form of memory: electronic. Le Goff highlights two direct consequences of this "electronic memory":

The first is the use of calculators in the domains of the social sciences, especially, that in which memory constitutes, at the same time, the material and the object: history. History lived a true documentary revolution-in fact, the computer here is no more than an element, and archival memory was 
revolutionary due to the appearance of a new type of memory: the database (2013: p. 429).

Therefore, the second consequence is the "extension" of the concept of memory and the comparison made of electronic memory with other forms of memory. Electronic memory has shown, in a more effective and clear way, the importance of the development of collective memory. Le Goff points out that:

In developed societies, new archives (oral and audiovisual) do not escape the vigilance of governments, even if they can control this memory as closely as the new tools that produce this memory, particularly that of radio and television (2013: p. 436).

Collective memory, states Le Goff, is a great achievement, but above all, an instrument and object of power as it becomes more collective. It is through historical memory that identities, individual or collective, can be constructed and reconstructed with diverse objectives. In this sense, the historian gains special prominence because, as his work, concerning the study of memory, develops, more ethical commitment is required of him. The French historian ends his text by appealing to historians of memory, where "memory, in which history grows, which in turn nourishes it, seeks to save the past to serve the present and the future. We must work, so that collective memory serves for the liberation and not for the servitude of men" (Le Goff, 2013: p. 437). The so-called "developed societies" demand even more this ethical-liberating-commitment concerning new forms of archives of the historian.

\section{History and Memory in Historical Production about Childhood}

\subsection{For a History of Childhood}

It is necessary to speak of childhood and its history from an academic perspective for several reasons. One of these is to see the child with its peculiarities, separated from the view of the child in the past: that of a mini-adult.

A history of childhood begins with the need to show an existing deficiency in historical narratives, in which the child has always been, in a certain way, marginalized as a subject with its peculiarities. The man, in his adulthood, is almost always the main actor in history. The child was practically excluded from the history as such, unless it was linked to the adult figure and/or participating in their world, after all, it was common for children to participate in practices of everyday life in the world of adults. This can be observed from the Industrial Revolution of the eighteenth century ${ }^{6}$, where children performed work activities in factories similar to those of adults.

Even though the child, as seen today, was incorporated into the adult world ${ }^{6}$ Despite the fact that children are now being found working in jobs that belong, or at least should belong only to the universe of adults, what differentiates today's view from that of the time is that until the eighteenth century, there was no criticism around child action in the world of work. In other words, a de facto separation of the child from the adult world as we have today. 
early in the centuries prior to the twentieth century, it was ignored as an actor in history both by men of the eighteenth century and by historians until the first half of the twentieth century, because, "in fact, for a long time, few historians dedicated to childhood. Still in the 1950s, its territory could be considered "an almost virgin field" (Heywood, 2004: p. 13. Author's emphasis). Like other fields of production of human knowledge, history "ignored" the child and a possible history of childhood. In the words of Heywood:

Even so, old ways of thinking about childhood persisted in the 20th century. Research on child rearing conducted in the areas of social children had to struggle to escape the narrow limits of psychological behaviorism. According to Hans Peter Dreitzel, until the 1960s, researchers considered the child as an "incomplete organism", which evolved in different directions in response to different stimuli. Once again, adulthood was the crucial stage of life, for which childhood was only a preparation stage. All the emphasis of anthropology, psychology, psychoanalysis, and sociology was on evolution and socialization. The important thing was to find ways to transform the immature, irrational, incompetent, antisocial, and a cultural child into a mature, rational, competent, social, and autonomous adult (2013: p. 11. Author's emphasis).

The fields of anthropology, psychology, psychoanalysis, and sociology, even if considerably turning their attention to children since the $1960 \mathrm{~s}$, seem to refer to the adult phase for specifically studying childhood. It was no different in history when we speak of childhood as a phase of life with peculiarities.

Writing a history of childhood with elements of its own, that is, from the point of view of childhood by childhood, is a very complex activity, after all, "a specific problem for historians is to dig up source materials about childhoods of the past. Children themselves do not leave many records" (Heywood, 2004: p. 14).

Such problems do not make a historical-scientific work about childhood unfeasible, precisely because of the specific scientific character of the historical production mentioned in the first part of this text. The method, the discipline and the problematizations that can be raised about certain sources, allow the historian to go beyond what they seem to say or show. Through the lens of history, as a specific scientific activity, even the "trail" of the child itself, which seems to be invisible in certain historical sources, becomes perceptible, because

Children left traces in several places, from Anglo-Saxon burials and reports of those in charge of medieval death records to contemporary documentation of heights, deaths, school attendance, and factory work. Adults also tried to remember their childhood years in autobiographies and during interviews with oral history specialists (Heywood, 2004: p. 15).

The sources about children, therefore, are infinite. However, the traces of the children of the past are a type of source that demands of the historian who study 
children, a refined sense, a special care in selecting their sources and problematizing them for a rich and sophisticated historical production that is new in the face of views that may even be almost crystallized with time.

\subsection{For a Memory of Childhood}

Building a historical narrative of childhood, with all the scientific requirements of history, in order to produce a historical work about memory of childhood is, in a way, a process that requires not only an ethical commitment of the historian, but a special care, because, being memory and identity elements that complete each other, in which memory is, par excellence, producer of a collective identity, the child and his childhood may be involved in games of interest-political, economic, ideological, and so on-in which not always being protagonist is something relatively positive.

Following the example of memory and its social function, we highlight an article by Professor Thiago F. Sant'anna (2011), which has as object of study some schools in the province of Goiás in the nineteenth century-more specifically from 1827 to 1887-, where school institutions created, which he expressed well, "possibilities for boys" and a "destiny for girls" throughout the lives of children who studied there. Analyzing documents of laws and official reports made by the provincial presidency regarding public education, the author realized that the educational policies of that time established an education based on gender, tracing an established destiny to girls, which was different from that of boys. Thus, such policies allowed the opening of a range of possibilities throughout the life of the latter, thus resulting in an inequality of possibilities based on gender.

Difference between genders becomes inequality when power networks challenge it, that is when social representations mark positions of inferiority of the subject's spaces and places of speech. An example of this is the configuration of female identity, which not only differs from male identity but also underpins a hierarchy, in which the masculine is seen as better and superior to the feminine (Sant'anna, 2011: p. 146. Author's emphasis).

The author reaches this conclusion analyzing, for example, the curricula that kept the so-called "needlework" in schools intended for girls, linking the life activity to domestic chores.

Throughout the text, the author presents the various policies aimed at public education of the time where the weight of a predetermined destiny was placed on the female body, even if such destiny was not only that of domestic work but also a possible non-domestic activity.

In summary, for boys, it demarcated the path of possibilities; for girls, the

${ }^{7}$ The author cites the regulations arising from the 1886 reform of public education, which maintained a historical gender differentiation in so-called primary education at that time. In the document that extended the curriculum to primary education, the author cites "Art. $2, \$ 5^{\circ}$ ". In women's schools, it will regulate the previous art, and the needlework (Sant'anna, 2011: p. 142). 
path of destiny, linked to the "south of the body"/womb, to motherhood, to the care of the other, even if it pointed to the practice of a job, the exercise of a profession or even, the participation of a social and political movement (Sant'anna, 2011: p. 147).

A historical work such as this, whose analytical basis the issue of gender, clearly demonstrates a social function of memory, since the possibility of its collectivization could even unveil the eyes of women who have not yet been able to see the reflections of this past that, in a certain way, still trace, cautiously and silently, the fate that awaits them and/or even already operates in their daily lives, extinguishing even the range of possibilities that were intended only for men. However, the social function of memory does not only apply to the field of political and ideological awareness, and so on; it is a fundamental part of the construction of identity.

If memory is one of the most essential elements of the construction, whether collective or not, of identity, a historian when referring to the past, property of memory par excellence with the aim of building a specific historical narrative of childhood and/or child, also builds new identity perspectives of its object which, in turn, reflects in present actions around the child and its childhood.

\section{The Social Function of History and Memory in the Constitution and Status of the Child and Adolescent}

If today children are legally protected, this, of course, is the result of a long historical process that included various ways of "looking" at how this occurred. History plays a fundamental role in this achievement of children's rights, since "history makes it possible to glimpse how the meaning of the concept of the child differs over time" (Valdez, 2003: p. 64). The Brazilian Federal Constitution of 1988 and the Statute of the Child and Adolescent of 1990 well endorse the concept of children that has been established over time.

Promulgated in 1988, the Brazilian Federal Constitution inaugurates the current legal scenario of rights directed to the child and adolescent since it places in charge of the State and the Family the duty of protecting them, according to Article 227:

It is the duty of the family, society and the State to ensure to children, adolescents and young people, with absolute priority, the right to life, health, food, education, leisure, professionalization, culture, dignity, respect, freedom, and family and community coexistence, in addition to leaving them safe from all forms of neglect, discrimination, exploitation, violence, cruelty, and oppression (Brasil, 1988).

Article 227 of the Brazilian Federal Constitution calls our attention to two views still present about children: that of being in a phase of life with its peculiarities-childhood-and the view of being a "mini-adult". In the first case, the protectionist aspect of the article refers to an individual who has not yet been 
inserted into the world of adults, being unable to live independently, thus needing to be constantly watched, protected; In the second case, the article does not separate it from the so-called phase of adolescence and youth, which makes the "right to professionalization", something left to the three initial phases of individuals' life, that is, children, adolescent and young people have the right to an activity linked to the preparation to work in the labor market, which, in our view, still links the child to a image of mini-adult.

Since 1990, with the creation of the Statute of the Child and Adolescent (Estatuto da Criança e do Adolescente-ECA), the conceptual aspect of children has taken a different meaning. Enacted on July 13, 1990, ECA is a direct result of this conceptual change of child regarding two aspects: 1) chronological conceptualization, since in Article 2, individuals aged between zero and twelve years old are considered as children, and, therefore, individuals aged between twelve to eighteen years old are considered as adolescents, and 2) the child not seen as an object subjected to intervention, but as individuals having rights, since before the ECA, the laws focused in children and adolescents were laws of punitive character, addressed to offenders. However, as the concepts about the child change over time, that is, they are not crystallized, these two forms of conceptualization of the child-chronological and having rights-present in the ECA is a fragile target, subjected to changes based on the conceptualization of the child that occur over time.

In 28 years of history, the ECA has been the target of several political demands and proposed laws. "In those 25 years, about 20 laws have come into force modifying the statute... Almost 300 proposals to change the ECA are still being analyzed in the Chamber of Deputies, more than 50 of them with the intention of hardening the punishment of offending adolescents" (CÂMARA, 2015). ${ }^{8}$ Fifty proposals stand out for proposing hardening of punishment to be applied to children and/or adolescents. We highlight some of them:

Among the proposals for amending the statute, one of the most recent is the Bill (Projeto de Lei-PL) 1.501, of 2015, of the federal deputy from Rio de Janeiro, Cabo Daciolo (former Psol, currently without party), which proposes that the socio-educational measures of internment-applied from the age of 12 in cases of criminal acts against the life of another person-be fulfilled in barracks of the Armed Forces.

The 2015 PL 387 by federal deputy Alberto Fraga (DEM/DF), in turn, proposes that internment measures should have the same duration as for crimes committed by adults. Thus, in the case of murder, adolescents could be in prison for up to 30 years. And from the age of 18, they would be transferred to a common prison unit.

${ }^{8}$ The source cited is a text written in 2015. However, due to the year of production of this article, the ECA is 28 years old now. From 2015 to the present day, there have been more proposals for laws that alter the ECA, such as Bill No. 5850/2016: "the bill proposes, among others, stability of employment for the adopter for five months after the granting of custody, maternity leave for those who adopt, regardless of the age of the child" (Brasil, 1990). This bill, like others, is part of the nearly 300 bills in Congress to be discussed and perhaps voted on in plenary. 
Federal Congressman Marcos Rogério (PDT/RO), through PL 7.553, 2014, intends to release images of the faces of children and adolescents who have committed criminal acts, under the justification that this would allow identifying more quickly the author of the act.

Another 30 projects propose increasing the length of stay to up to eight years. Currently, the maximum length of stay is three years, which can be followed by three more years of partial freedom and three more years of assisted freedom (Gomes, 2015).

In addition to the proposed amendments to the ECA, there are also Proposals for Constitutional Amendments (PEC) underway in the National Congress that ask for the reduction of the legal age, and there are texts that propose the reduction of lawful age from 18 to 16 years, 15 years and even 14 years, depending on the author of the proposal. Now, it seems that these laws with a more punitive character represent a step backward, since they may be a sign of the return of a form of legal norms that existed before the ECA was constituted as a document that sees the child and adolescent as subjects who have rights.

Several attacks have taken place in the last twenty-eight years on the rights expressed both in the Federal Constitution and in the Statute of the Child and Adolescent, which clearly demonstrates that such actions are reflections of a new look at the child. In this sense, the laws already sanctioned and those in progress in Congress directly reflects a new view that one has about children, after all, their childhood seems to be reduced even further, chronologically speaking. There are no proposals to change the chronological concept of what comes to be child in the ECA - from the date of birth to 12 years old-, but the reduction of age of criminal responsibility increase of penalty for young people up to 14 years, for example, seems to be a direct reflection of the view that individuals in the phase understood between childhood and adult phase are still minors.

Questions such as: Since its creation, are the rights provided for in the ECA, as described in Article 4, were materialized? ${ }^{9}$ Why is there more interest in changing the text of the ECA than in verifying whether what it predicts is fulfilled? We do not risk giving answers to such questions, but we affirm here that the effect of the conception of the child, the memory, or the lack of it that one has about childhood is a fundamental factor of the infinite proposals for changes that are "drawn" around these normative documents. To what extent a history of childhood, produced with the scientific rigors of history, can influence, either negatively or positively, the policies expressed in official documents aimed at children? Perhaps the force of this is greater than a historian would imagine, a pity "'Art. 4 It is the duty of the family, the community, society in general and the public power to ensure, with absolute priority, the realization of the rights related to life, health, food, education, sport, leisure, professionalization, culture, dignity, respect, freedom, and family and community life. Single paragraph. The guarantee of priority includes: 1) primacy of receiving protection and help in any circumstances; 2 ) precedence of care in public services or of public relevance services; 3 ) preference in the formulation and execution of public social policies; 4) privileged allocation of public resources in areas related to the protection of children and youth" (Brasil, 1990. Emphasis present in the original text of the ECA). 
that many of them may have no idea of it.

\section{Conclusion}

Scientific production directly reflects on society, depending on the degree of "utility" that it can offer to it. Medicine, for example, is a classic example of the social use of its scientific productions, as well as Law which, based on its reflections and principles, acts directly in the construction of laws, chemistry, physics, psychology, and so on. All those have a social function of practicality that does not fit into the same social function of history.

The particularity of the social function of history is, as Le Goff stated, the sense that the past gives to the present, and one of the most significant meanings of this is the study of memory, because it is through memory that a game between different interests, political and ideological, of the historian, whom the historian "serves", and the ideology that surrounds him, is played. Through memory, the individual or collective identity and diverse concepts, such as that of child, are constructed. Through history, memory is built, and through memory, history is manipulated.

In his work (2013), Le Goff warned about mixing history and politics, although the second was not absent from the first. The historian who is willing to attend to political interests in his writing consciously may have no idea of the force that his work has. The abuse of history lies precisely in the fact that the historian is a political partisan who, in the service of power interests, imprisons individuals. When the historian serves political interests, with the objective of building a collective memory, history, as Paul Valéry says, "becomes the most dangerous product that the chemistry of the intellect has developed" (apud Le Goff, 2013: p. 35). It is not by chance that Le Goff sees in the legitimization of history as science from a method of production with the rigors of an academic body that analyzes a specific historical production, a good and efficient way out of what he called "abuses of history", thus, in the footsteps of the historian, we realize that the scientific aspect of history can be its greatest strength for serving a social harmony.

Memory as an object of study of history must be an element not only of pure and straightforward knowledge, that is, knowledge but knowledge, but by having memory as an object of study, history must promote a liberating and not oppressive activity as in certain cases, in specific periods, it did and still does. It is based on this that we argue that: at this time, when the rights of the child are being redesigned, history must be the protagonist. The production of a history and memory of children may become the main element in the fight against the oppression of children which, of course, will be reflected in the adult that they will become.

\section{Acknowledgements}

We thank IF Goiano forfinancial support. 


\section{Conflicts of Interest}

The authors declare no conflicts of interest regarding the publication of this paper.

\section{References}

Brasil (1988). Constituição da República Federativa do Brasil de 1988. http://www.planalto.gov.br/ccivil_03/Constituicao/Constituicao.htm

Brasil (1990). Estatuto da criança e do adolescente e legislação correlata (recurso eletrônico): Lei no 8.069 de 13 de julho de 1990, e legislação correlata (12th ed.). Brasília: Câmara dos Deputados, Edições Câmara. http://www.planalto.gov.br/ccivil_03/leis/18069.htm

CÂMARA (2015). ECA completa 25 anos; quase 300 propostas na Câmara tentam mudar a lei.

http://www2.camara.leg.br/camaranoticias/noticias/direitos-humanos/492094-eca-com pleta-25-anos-quase-300-propostas-na-camara-tentam-mudar-a-lei.html

Gomes, R. (2015). Congresso Nacional tem pelo menos 300 propostas de alteração do ECA em tramitação. https://www.redebrasilatual.com.br/cidadania/2015/07/congresso-nacional-tem-pelomenos-300-propostas-de-alteracao-do-eca-em-tramitacao-611.html

Heywood, C. (2004). Uma história da infância: Da idade média à época contemporânea no Ocidente (Tradução Costa, R.C.). Porto Alegre: Artmed.

Le Goff, J. (2013). História e Memória (Tradução Leitão, B., et al., 7th ed.). Campinas: Editora da Unicamp.

Sant'anna, T. F. (2011). Possibilidades aos meninos, destinos às meninas? A Escola Primária como tecnologia de gênero na Província de Goiás (1827-1887). In: V. M. L. D. Barra (Ed.), Estudos de História da Educação de Goiás (1830-1930) (pp. 131-149). Goiânia: Editora da PUC/GO.

Valdez, D. (2003). História da Infância em Goiás: Séculos XVIII e XIX. Goiânia: Editora Alternativa. 